\title{
Autumn Cultivation of Farewell-To-Spring (Clarkia amoena A. Nelson \& J. F. Macbr.) in Unheated Foil Tunnel in Lower Silesia Condition
}

\author{
Przemysław Bąbelewski and Magdalena Pancerz \\ Department of Horticulture, Wroctaw University of Environmental and Life Sciences, Wroctaw 50-363, Poland
}

\begin{abstract}
In conditions of Poland, farewell-to-spring never was cultivated for cut flowers in unheated foil tunnel. Specific conditions of Lower Silesia, together with the short cultivation cycle and small demands of this plant, are promised for its cultivation in this region of Europe. The aim of the study was to evaluate the usefulness of two farewell-to-spring varieties for the cultivation for cut flowers in unheated foil tunnel in Lower Silesia conditions during autumn time. The two-factorial experiment was carried out by the method of random blocks in Research-Development Station of Vegetable and Ornamental Plants of Wrocław University of Environmental and Life Sciences. The first factor was the variety- "Grace White" and "Brillant" and the second was the year of cultivation-2012 and 2013. Measurements included number and length of flower stems, number of flower buds and leaves per flower stem, fresh and dry weight of flower stem and leaves color parameters. Total chlorophyll content was also determined. Studies showed that autumn cultivation of farewell-to-spring is reasonable because of its high yield (about 640 flower stems $/ \mathrm{m}^{2}$ ) with long flower stems from $50 \mathrm{~cm}$ up to $80 \mathrm{~cm}$. In Lower Silesia conditions, the variety "Grace White" has proven to be better; it produced higher number of flower stems with higher number of lowers buds and thus flowers. In terms of thermal conditions, more favorable was year 2013, in which the plants produced longer flower stems and had higher total chlorophyll content in leaves. After inserting the flower stems in tap water, all flower buds developed.
\end{abstract}

Key words: Farewell-to-spring, autumn cultivation, foil tunnel, cut flowers, Lower Silesia.

\section{Introduction}

Farewell-to-spring (Clarkia amoena (Lehm.) A. Nelson \& J. F. Macbr.) occurs naturally in the Southwestern United States in the area of California [1]. Sometimes, it is commonly called in Poland as summer azalea, because its flowers resemble potted azaleas. Other common names are godetia or satin flower [2]. The plant is cultivated as annual and used for flowerbeds decoration. In Poland, it is cultivated occasionally for cut flowers in the ground, but it remains very popular in Italy and Israel. In warm states of North America, it can be grown throughout the year. The best condition for its growth is dry climate with low temperature, thanks to their flowering that can be controlled [3].

Corresponding author: Magdalena Pancerz, M.Sc., research fields: ornamental plants and dendrology.
In Poland, interest in energy-saving production increases due to high heating costs. One of the most important alternatives is searching for cultivation of attractive ornamental plants with small thermal requirements. Farewell-to-spring cultivated for cut flowers in unheated foil tunnel can be included to group of such plants. In climate conditions of Poland, Chrysanthemum, sweet peas, Alstroemeria and Dianthus are commonly grown for cut flowers [4]. In Western Europe, there have also been developed efficient methods of cultivation of ornamental plants, such as Persian cyclamen, true oxlip and dusty miller [5].

In Poland, farewell-to-spring has never been cultivated in unheated foil tunnel for cut flowers before. Specific conditions of Lower Silesia are promised for its cultivation and give a chance to increase the assortment of cut flowers on Polish market during autumn season. Short production cycle 
and low thermal demands of this plant prompted the authors of this research to evaluate the usefulness of two farewell-to-spring varieties-"Grace White" with white flowers and "Brillant" with single carmine-pink flowers.

\section{Materials and Methods}

The two-factorial experiment was set up by the method of random blocks in Research-Development Station of Vegetable and Ornamental Plants of Wrocław University of Environmental and Life Sciences. The first factor was the variety of farewell-to spring_-"Grace White" and "Brillant" (W. Legutko, Poland). The second factor was year of cultivation; experiment was carried out in 2012 and repeated with the same method in 2013. Seeds were sown to multi-pots in peat substrate in early July. In early August, seedlings size of 12-15 cm were planted on the ground ridges under unheated foil tunnel with dimensions $9 \mathrm{~m} \times 30 \mathrm{~m}$, spacing $25 \mathrm{~cm} \times 15 \mathrm{~cm}$ on plots $5 \mathrm{~m} \times 2 \mathrm{~m}$. Each variety was planted in four replications (plots) for 30 plants. Soil on ridges belongs to class IIIa (good arable land complex), ranked as degraded light clays, which was enriched with peat substrate (Klasmann, Germany) (at dose 200 $\mathrm{dm}^{3} /$ plot) in order to loosen its structure. The organic matter content was at level of $2.8 \%$, the $\mathrm{pH}$ (determined in distilled water at a volume ratio of 2:1 water to soil) was 8.2 and the salinity $155 \mu \mathrm{S} / \mathrm{cm}$. The nutrient content was $55 \mathrm{mg} / \mathrm{dm}^{3} \mathrm{~N}^{-N^{-}}{ }_{3}^{-}, 37 \mathrm{mg} / \mathrm{dm}^{3} \mathrm{P}$, $138 \mathrm{mg} / \mathrm{dm}^{3} \mathrm{Mg}, 125 \mathrm{mg} / \mathrm{dm}^{3} \mathrm{~K}$ and 4,800 mg/dm ${ }^{3} \mathrm{Ca}$. In late August, plants were top dressed with Yara Milla complex fertilizer, which was composed of $12 \%$ $\mathrm{N}$ (including 5\% $\mathrm{N}^{-\mathrm{NO}_{3}}{ }^{-}$and $7 \% \mathrm{~N}^{-\mathrm{NH}_{4}}$ ), $11 \%$ $\mathrm{P}-\mathrm{P}_{2} \mathrm{O}_{5}, 18 \% \mathrm{~K}-\mathrm{K}_{2} \mathrm{O}, 2.7 \% \mathrm{Mg}-\mathrm{MgO}, 8 \% \mathrm{~S}, 0.015 \%$ $\mathrm{B}, 0.2 \% \mathrm{Fe}, 0.02 \% \mathrm{Mn}$ and $0.02 \% \mathrm{Zn}$ at a dose of 3 g/plant. After 13 weeks (in the first decade of November), in the phase of one developed flowers number and length of flower stems, flower buds and number of leaves were measured and total chlorophyll content and leaves color parameters were determined.
Then half of the plants from each replication (15) were collected to determine the fresh and dry weight of flower stems, the other half was collected for cut flower. After inserting flower stems in the tap water, the ability of flower buds to develop into flowers was evaluated.

The color of the leaves was determined in fresh leaves, just after collection with a HunterLab MiniScan EZ colorimeter in reflected light in the range of $400-700 \mathrm{~nm}$ using a scale of CIE $\mathrm{L}^{*} \mathrm{a} * \mathrm{~b}^{*}$. The parameter $\mathrm{L}^{*}$ (brightness) has a value from 0 (black) to 100 (white). For the parameter a* (tone color), the positive determines the amount of red color, while the negative stands for green color. For the parameter $b^{*}$ (tone color), the positive determines the amount of yellow color, while the negative is blue color amount. Chlorophyll content was determined in fresh weight of leaves using spectrophotometric method.

The data were subjected to the analysis of variance (ANOVA). The $F$-test was used to identify the treatments main effects and interactions followed by Tukey's range test at the 0.05 significance level.

Lower Silesia is the region of Poland with the longest vegetation period that lasts $226 \mathrm{~d}$. The longest thermal season in summer lasts $92 \mathrm{~d}$, starting from July 1st. Autumn starts at September 1st and lasts $68 \mathrm{~d}$. Wrocław is the warmest city in Poland with average year air temperature exceeding $8.7{ }^{\circ} \mathrm{C}$. Moreover, urban heat island effect is very pronounced, where the increase in annual mean temperature is about $1.5^{\circ} \mathrm{C}$ and the mean monthly temperatures reach $3-7{ }^{\circ} \mathrm{C}$ as compared to suburban areas $[6,7]$. The temperature curve during cultivation of farewell-to spring is shown in Table 1.

\section{Results and Discussion}

Cultivation of farewell-to-spring in conditions of Lower Silesia in unheated foil tunnel is possible. The "Grace White" variety produced more flower stems in comparison to "Brillant". Research conducted by 
Table 1 Mean air temperature $\left({ }^{\circ} \mathrm{C}\right)$ during cultivation of farewell-to-spring for cut flowers in unheated foil tunnel.

\begin{tabular}{llllll}
\hline \multirow{2}{*}{ Year } & \multicolumn{5}{c}{ Temperature in different months } \\
\cline { 2 - 6 } & July & August & September & October & November \\
\hline 2012 & 20.1 & 19.7 & 14.8 & 5.6 & 0 \\
2013 & 20.0 & 21.0 & 13.8 & 11.6 & 5.8 \\
Long-term average 1991-2000 & 18.9 & 18.7 & 14.0 & 9.0 & 3.4 \\
\hline
\end{tabular}

Table 2 Mean values of selected morphological features of farewell-to-spring.

\begin{tabular}{|c|c|c|c|}
\hline \multirow{2}{*}{ Variety } & \multicolumn{2}{|c|}{ Year } & \multirow{2}{*}{-Mean } \\
\hline & 2012 & 2013 & \\
\hline \multicolumn{4}{|c|}{ Number of flower stems } \\
\hline "Grace White" & $23.92^{\mathrm{b}}$ & $28.60^{\mathrm{a}}$ & $26.27^{\mathrm{a}}$ \\
\hline "Brillant" & $24.32^{\mathrm{b}}$ & $20.75^{\mathrm{b}}$ & $22.54^{\mathrm{b}}$ \\
\hline Mean & 24.13 & 24.68 & \\
\hline \multicolumn{4}{|c|}{ Length of flower stems (cm) } \\
\hline "Grace White" & $53.08^{\mathrm{b}}$ & 73.07 & 63.39 \\
\hline "Brillant" & $57.35^{\mathrm{b}}$ & $80.25^{\mathrm{a}}$ & 68.80 \\
\hline Mean & $55.21^{\mathrm{b}}$ & $76.98^{\mathrm{a}}$ & \\
\hline \multicolumn{4}{|c|}{ Number of flower buds per flower stem } \\
\hline "Grace White" & $15.50^{\mathrm{b}}$ & $20.25^{\mathrm{a}}$ & $17.87^{\mathrm{a}}$ \\
\hline "Brillant" & $14.25^{\mathrm{b}}$ & $15.50^{\mathrm{b}}$ & $14.87^{\mathrm{b}}$ \\
\hline Mean & $14.89^{\mathrm{b}}$ & $17.89^{\mathrm{a}}$ & \\
\hline \multicolumn{4}{|c|}{ Number of leaves per flower stem } \\
\hline "Grace White" & 89 & 95 & 92 \\
\hline "Brillant" & 90 & 92 & 91 \\
\hline Mean & 90 & 94 & \\
\hline
\end{tabular}

a, b Means with different letters are statistically different.

Janowska [8] also indicates that various varieties of carnation may differ in number of flower stems. In this study, a factor - the year of cultivation had no effect on the number of flower stems of farewell-to-spring. Taking into account factors interaction, most flower stems were produced by "Grace White" variety in the second year of study, while "Grace White" in 2012 and "Brillant" in both years of cultivation resulted in the least (Table 2). In case of carnation, different numbers of flower stems of varieties were obtained in subsequent years of research. The variety "Rapid Weiss" produced the most flowers stems in the first year of cultivation, while "Heitmatland" and "Pink Beauty" varieties yielded better in the second year of cultivation [8].

In 2012 both varieties produced shorter flower stems and in 2013 flower stems length increased almost $40 \%$, comparing to the previous year. Taking into account the factors interaction, in 2012 both varieties "Grace White" and "Brillant" were statistically the lowest, while in 2013 the highest was farewell-to-spring "Brillant" variety (Table 2). Analyzing farewell-to-spring flower stems length in relation to the tested varieties, it was found that there was no effect on this characteristic. In studies of Janowska [8], also no significant difference in length was found between the flower stems of carnation varieties grown in unheated foil tunnel.

More flower buds formed plants in the variety "Grace White". In 2013 both varieties of farewell-to-spring produced more flower buds than in 2012. The greatest number of flower buds was observed in "Grace White" variety in 2013. On average, "Grace White" variety had the least of flower buds in 2012 and "Brillant" had the least flower buds in both years of cultivation (Table 2). It can be seen that the number of flower 
buds was closely related to the number of flower stems. Obtained results were confirmed by Czekalski and Czemplik [9] in their research of farewell-to-spring cultivation for cut flowers in ridges on open ground. In this case, the variety, which produced the most of side shoots and thus had the most flower buds, was "Karminowa" variety.

In 2012, "Grace White" variety started flowering on November 8th, while "Brillant" did on November 10th. In 2013, both varieties started flowering earlier than previous year, on November 1 st and on November 5th, respectively. It might be caused by temperature curve during cultivation. Optimum temperature for farewell-to-spring is $15-18^{\circ} \mathrm{C}$ [3], and in October and November of 2013, during flower buds setting and flowers development, the temperature was higher (Table 1).

Flower stems were collected in phase of one developed flower, but ultimately after placing in water all flower buds developed into flowers. These results are confirmed by Czekalski and Czemplik [9]. After placing flowers shoots in water, regardless of its type and the addition of conditioner, all flower buds developed. Also, the research of Anderson [10] showed that all flower buds opened to normal size and color, moreover, performance in tap water was superior to performance in a commercial preservative solution. These results highlight the usefulness of farewell-to-spring for cut flowers production not only because of the opening up of all flower buds, but also due to its small requirements.

On the basis of the plants density and the number of

Table 3 Mean values of fresh and dry weight of flower stems, total chlorophyll content and color parameters of leaves.

\begin{tabular}{|c|c|c|c|}
\hline \multirow{2}{*}{ Variety } & \multicolumn{2}{|c|}{ Year } & \multirow{2}{*}{ Mean } \\
\hline & 2012 & 2013 & \\
\hline \multicolumn{4}{|c|}{ Fresh weight of flower stem $(\mathrm{g})$} \\
\hline "Grace White" & 11.70 & 12.60 & 12.15 \\
\hline "Brillant" & 11.80 & 12.40 & 12.10 \\
\hline Mean & 11.75 & 12.50 & \\
\hline \multicolumn{4}{|c|}{ Dry weight of flower stem (g) } \\
\hline "Grace White" & 5.2 & 5.6 & 5.4 \\
\hline "Brillant" & 5.0 & 5.4 & 5.2 \\
\hline Mean & 5.1 & 5.5 & \\
\hline \multicolumn{4}{|c|}{ Total chlorophyll content (mg/g of fresh weight) } \\
\hline "Grace White" & 0.806 & 0.934 & 0.870 \\
\hline "Brillant" & 0.805 & 0.921 & 0.863 \\
\hline Mean & $0.806^{\mathrm{b}}$ & $0.928^{\mathrm{a}}$ & \\
\hline \multicolumn{4}{|l|}{ Brightness L* } \\
\hline "Grace White" & 32.88 & 35.88 & 34.38 \\
\hline "Brillant" & 33.43 & 34.46 & 33.95 \\
\hline Mean & $33.16^{\mathrm{b}}$ & $35.17^{\mathrm{a}}$ & \\
\hline \multicolumn{4}{|l|}{ Tone color $\mathrm{a}^{*}$} \\
\hline "Grace White" & -8.81 & -9.31 & -9.06 \\
\hline "Brillant" & -8.86 & -8.99 & -8.93 \\
\hline Mean & -8.84 & -9.15 & \\
\hline \multicolumn{4}{|l|}{ Tone color b* } \\
\hline "Grace White" & 12.07 & 12.61 & 12.34 \\
\hline "Brillant" & 12.26 & 12.54 & 12.40 \\
\hline Mean & $12.17^{\mathrm{b}}$ & $12.58^{\mathrm{a}}$ & \\
\hline
\end{tabular}

${ }^{\mathrm{a}, \mathrm{b}}$ Means with different letters are statistically different. 
flower stems per single plant, the yield of flower stems $/ \mathrm{m}^{2}$ can be estimated. At a density ratio of 26.7 plants and harvest an average of 24 stems/plant, yield of flower stems will be shaped to an average of 640.8 stems. The obtained result is satisfactory. In the experiment conducted by Topa and Tallarico [11] in Italy in the spring cultivation of farewell-to-spring from one plant, they achieved an average yield of 5.6 stems/plant, which give 112 flower stems $/ \mathrm{m}^{2}$. In addition, $88 \%$ of collected stems were classified as class I (stem length of $50-55 \mathrm{~cm}$ ), while in this research all plants exceed height of $50 \mathrm{~cm}$ even in the first year of study, in which both varieties were statistically the lowest.

None of the factors nor their interaction had influence on number of leaves of per flower stem (Table 2), as well as on fresh and dry weight of flower stems (Table 3). Total chlorophyll content was determined only by the year of cultivation and was higher in 2013 (Table 3). It might be associated with temperature during measurements; in November 2012, average temperature was $0{ }^{\circ} \mathrm{C}$ and in low temperatures chlorophyll breaks down. Taking into account the color parameters of leaves, the year of cultivation influenced brightness of leaves and tone color $b^{*}$. In 2013 leaves were brighter and had more yellow tone color, while in 2012 they were darker and less yellow. None of the factors nor their interaction had influence on tone color $\mathrm{a}^{*}$.

There are many indications that farewell-to-spring could become a popular cut flower in Poland. Temperature curve in Lower Silesia during autumn cultivation is close to optimum and allows to obtain high yield of long flower stems. To make cultivation of this plant beneficial for polish producers, more acceptance from consumers is needed, which will influence the demands for this plant and its availability on the Polish market.

\section{Conclusions}

Autumn cultivation of farewell-to-spring is reasonable because of its high yield of long flower stems. Variety that produced higher number of flower stems with higher number of lowers buds and thus flowers was "Grace White". In 2013, plants produced longer flower stems, had higher total chlorophyll content in leaves, but leaves were brightener and had more yellow tone color than previous year. After inserting the flower stems in tap water, all flower buds developed.

\section{References}

[1] Pojar, J., and MacKinnon, A. 1994. Plants of the Pacific Northwest Coast: Washington, Oregon, British Columbia and Alaska. Redmond, Washington: Lone Pine Pub., 209.

[2] Young-Mathews, A. 2012. "Plant Fact Sheet for Farewell to Spring (Clarkia amoena)." USDA-Natural Resources Conservation Service, Corvallis Plant Materials Center, Corvallis, Oregon. Accessed September 2014. http://plants.usda.gov/factsheet/pdf/fs_clam.pdf.

[3] Hanks, G. 2013. "Field- and Tunnel-Grown Cut Flowers with Potential for UK Exploitation: A Review of Trials Programmes and Research on 'Novel' Subjects." The National Flower Center. Accessed November 6, 2013. http://www.thecutflowercentre.co.uk/wp-content/uploads/ 2013/11/Cut-Flower-Review-Final.pdf.

[4] Czekalski, M. 2005. "General Cultivation of Ornamental Plants.” Wydawnictwo Uniwersytetu Przyrodniczego we Wrocławiu, Poland. (in Polish)

[5] Hentig, W. U. 1982. "Agronomic Potential for Energy Saving." Gaertnerbörse Und Gartenwelt 34: 768-88. (in German)

[6] Dubicki, A., Dubicka, M., and Szymanowski, M. 2002. "Climate of Wrocław." Environment of Wrocław-Directory 2002, Dolnośląska Fundacja Ekorozwoju, Wrocław. (in Polish)

[7] Dubicka, M., and Dubicki, A. 2006. "Environment of Wrocław.” Environment Institute Wrocław. (in Polish)

[8] Janowska, B. 2000. "The Cultivation of Dianthus barbatus L. in Unheated Plastic Tunnel." Rocz. AR Pozn. Ogrodn. 29: 61-4. (in Polish)

[9] Czekalski, M., and Czemplik, S. 2003. "Godetia for Cut Flowers." Ornamental Plants 3: 24-5. (in Polish)

[10] Anderson, R. G. 1998. "Clarkia." In Ball Red Book, 16th ed., edited by Ball, V. Batavia, IL: Ball Publishing Co., 426-32.

[11] Topa, V., and Tallarico, A. 1992. "Cultivation of Godetia for Cut Flowers.” Il Floricultura-Luglio: 27-29. (in Italian) 